\title{
DEVELOPMENT OF A NEW TOOL FOR FISH-BASED RIVER ECOLOGICAL STATUS ASSESSMENT IN POLAND (EFI+IBI_PL)
}

\author{
Mikołaj ADAMCZYK ${ }^{1,2}$ *, Paweł PRUS ${ }^{1}$, Paweł BURAS ${ }^{1}$, Wiesław WIŚNIEWOLSKI ${ }^{1}$, \\ Janusz LIGIĘZA ${ }^{1}$, Jacek SZLAKOWSKI ${ }^{1}$, Irena BORZECKA ${ }^{1}$, and Piotr PARASIEWICZ ${ }^{1}$ \\ ${ }^{1}$ The Stanisław Sakowicz Inland Fisheries Institute, River Fisheries Department, Żabieniec, Piaseczno, Poland \\ ${ }^{2}$ Ecole Polytechnique Fédérale de Lausanne (EPFL), Laboratory of Hydraulic Constructions (LCH), Lausanne, \\ Switzerland
}

\begin{abstract}
Adamczyk M., Prus P., Buras P., Wiśniewolski W., Ligięza J., Szlakowski J., Borzęcka I., Parasiewicz P. 2017. Development of a new tool for fish-based river ecological status assessment in Poland (EFI+IBI_ PL). Acta Ichthyol. Piscat. 47 (2): 173-184.
\end{abstract}

\begin{abstract}
Background. Fish-based indices for evaluation of river ecosystem quality have been used since the 1980s, when the Index of Biotic Integrity (IBI) was first introduced. Assessment of the ecological status of rivers, based on fish assemblages is required by the Water Framework Directive. During last 15 years a number of national assessment methods based on fish fauna were developed. The recently designed tool for fish-based assessment of ecological status (EFI+IBI_PL) applied in river monitoring in Poland is presented in this paper.

Material and methods. The new European Fish Index EFI+ is a multimetric tool consisting of two specific indices, each with two metrics developed separately for salmonid- and cyprinid-river zones. Those metrics were used in the European intercalibration process to validate national methods. However, the original EFI+ method is not adequate to some lowland river types (physical-factor classification), so it was complemented by a typespecific modification of the Index of Biotic Integrity (IBI_PL). The method was tested on fish data from 493 sites located in 431 surface water bodies sampled in 2011-2012 according to the CEN standard 14011.

Results. The EFI+ index was adapted to the specificity of Polish rivers by eliminating some inconsistences of the ecoregion division and problems related to the lack of the Dniester River in the EFI+ software and presented in this paper as EFI+PL. The index of diadromous fish occurrence (D) was also adapted from an original EFI+ method and used as a supplementary assessment tool. Specific IBI metrics were developed for large lowland rivers (with sandy or gravel bottom substrate), organic rivers (flowing through peat areas), and rivers connecting lakes (with the presence or lack of salmonid fish species). A software tool for indices calculation was also developed. The method combination (EFI+IBI PL) was than tested on a set of 493 monitoring sites sampled in 2011-2012. Both indices classified the highest percentage of sites into moderate ecological state/potential class, but for IBI PL this percentage was much higher than for EFI+. Percentage of sites classified to good ecological status or high ecological potential by IBI_PL index were lower than for EFI+. The analysis indicates the consistence of classification for $77 \%$ of sites to $\bar{h}$ igh/good and below good ecological status by the EFI+PL/IBI_PL method and pressure index.

Conclusion. The results of a two-years monitoring program show that the combination of modified EFI+ and IBI methods can be applied as a tool for river ecological status assessment in Poland, however some further method modifications are needed.
\end{abstract}

Keywords: ecological status, new European Fish Index, ichthyofauna, biotic integrity, multimertric index, river

\section{INTRODUCTION}

The assessment of ecological status of the aquatic environment using biological elements is now a standard in the European Union. The Water Framework Directive (Anonymous 2000) requires the use of phytoplankton, phytobenthos, macrophytes, macroinvertebrates, and fishes as biological quality elements for determination of the ecological status of rivers. Fish communities are considered good indicators of river environmental state (Pont et al. 2006, Schmutz et al. 2007, Anonymous 2009), and have several advantages as indicator organisms (Fausch et al. 1990, Harrison and Whitfield 2004). Fish are present 
in almost all lotic ecosystems. As long-living organisms (in comparison to other groups - e.g., phytoplankton), the fish reflect cumulative effects of long-term anthropogenic stressors. Due to their high mobility, fish use various habitats within river ecosystems, so they are particularly sensitive to disturbances in river morphology, which are common in Europe (Schinegger et al. 2011). Fish are also the only riverine organisms actively migrating over long distances, so they are especially influenced by the river continuum disturbances. Diadromous species are a particularly vulnerable group (Wiśniewolski and Engel 2006). The number of fish species in European inland waters is limited to about 250 species. Moreover, in the majority of cases, those fishes are easy to identify to the species level.

Fish-based indices for evaluation of river ecosystem quality have been used since the 1980s, when the Index of Biotic Integrity (IBI) was first introduced (Karr 1981, Karr et al. 1986). This method includes 12 metrics, divided into three categories:

- Species richness and composition;

- Trophic structure;

- Fish abundance, health, and condition.

A matrix of these biological metrics is used to calculate an IBI score, which is the foundation for validation of environmental quality and environmental status assessment. An Index of Biotic Integrity is a precise method that can be calibrated for particular river type or catchment. However, creating the specific IBI matrix for each river type or catchment requires a lot of data and the index was mainly used to assess rivers on a catchment scale (Buras et al. 2004, 2006, Szlakowski et al. 2004). Therefore it is difficult to implement the original IBI method in standard monitoring systems, as the State Environmental Monitoring performed in Poland by the Chief Inspectorate of Environmental Protection.

The IBI index was a base for further development of fish-based methods of river biological quality assessment. In 2004, the multimetric European Fish Index (EFI) was developed within an international FAME project. It was intended as a standard tool for river biological quality assessment in Europe, in accordance to the WFD (Water Framework Directive) requirements (Anonymous 2000, 2004, Pont et al. 2006, Schmutz et al. 2007). The method used 10 metrics grouped in five categories:

- Trophic structure;

- Spawning guilds;

- Habitat guilds;

- Tolerance to disturbance;

- Migration (Anonymous 2004).

However, in Poland, the correlation between the EFI assessment results and pressure level was strongest for small, upland rivers sampled using a wading method, which were numerous in the database used for index development. This dependence was much less pronounced for other river types, especially large and organic rivers*
(Wiśniewolski et al. 2006, Prus et al. 2009). Also, the spatial range of the EFI method was restricted to $15 \mathrm{EU}$ countries and data from 10 new member states (including Poland), which entered the EU in 2004, were poorly represented in the EFI database. For these reasons, a new project was undertaken to develop a common European fish index. The project, entitled: "Improvement and spatial extension of the European Fish Index EFI+" was conducted in 2007-2009 by a consortium of 14 institutions from 13 EU countries, led by the Universität für Bodenkultur in Vienna, including the Stanisław Sakowicz Inland Fisheries Institute from Poland. The project database consisted of 14000 fished sites on 2700 rivers in 15 EU countries, including 919 sites from Poland. Data on fish catches (electrofishing by wading or by boat) and anthropogenic pressure level were gathered for each site (Shinegger et al. 2011). This database was used to create a new European Fish Index (EFI+) (Anonymous 2009).

The EFI+ index consists of four metrics, selected from a number of candidate metrics tested (Bady et al. 2009). These metrics are grouped in pairs for two river types distinguished: salmonid- and cyprinid-dominated rivers. The index value is calculated as arithmetic mean of two metrics scores. The following metrics were selected for salmonid-dominated rivers:

- Density of fishes intolerant to oxygen depletion;

- Density of fishes smaller than $150 \mathrm{~mm}$ (total length), intolerant to habitat degradation.

For cyprinid-dominated rivers other two metrics were chosen:

- Richness of rheopar species;

- Density of species requiring lithophilic reproduction habitat (Table 1).

The river type (salmonid or cyprinid) is assessed automatically by the EFI+ software, based on physical parameters and proportion of intolerant salmonid species. However, in some cases this process needs expert verification, in case when share of intolerant salmonid species does not correspond to physical parameters, like slope characteristics or sediment granulation (Anonymous 2009). The method also has an additional module for assessment of diadromous fish species alteration at a given site, based on a simple ratio of the number of species historically occurring in a river to those currently present.

The EFI+ metrics were used as common metrics in the intercalibration process for the European fish-based methods of river biological quality assessment, conducted in 2009-2011. This method was selected due to its broad geographical range and suitability for Scandinavia, Mediterranean, European Atlantic coasts, and eastern Carpathian rivers (Anonymous unpublished ${ }^{* *}$ ). Despite this broad applicability, the EFI+ method has still some restrictions. For example, it is not applicable to organic rivers and rivers connecting lakes, or to oxbow lakes and other floodplain habitats. This is due to specific character of organic rivers, with soft bottom deposits, low water

\footnotetext{
* i.e., flowing through peat areas; the term introduced by Anonymous (2009).

"** Anonymous 2011. WFD Intercalibration. Phase 2: Milestone report-October 2011. European Commission Directorate General, JRC Joint Research Centre, Institute of Environment and Sustainability. Joint Research Centre documents.
} 
Table 1

List of species occurring in Poland considered by EFI+PL metrics according to Anonymous 2009

\begin{tabular}{|c|c|c|c|c|c|}
\hline \multicolumn{6}{|c|}{ EFI+PL Index metrics } \\
\hline \multirow{35}{*}{ 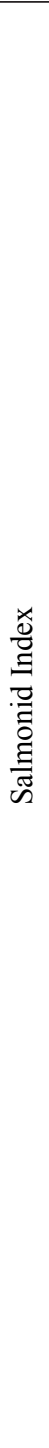 } & Ni.O2.Intol & Ni.Hab.Intol.150 & & Ric.RH.Par & Ni.LITHO \\
\hline & Alburnoides bipunctatus & Abramis ballerus & & Abramis sapa & Abramis ballerus \\
\hline & Aspius aspius & Acipenser oxyrinchus & & Acipenser oxyrinchus & Abramis sapa \\
\hline & Barbus cyclolepis & Acipenser sturio & & Acipenser sturio & Acipenser oxyrinchus \\
\hline & Barbus peloponnesius & Alburnoides bipunctatus & & Alburnoides bipunctatus & Acipenser sturio \\
\hline & Chondrostoma nasus & Barbus barbus & & Alosa alosa & Alburnoides bipunctatus \\
\hline & Coregonus lavaretus & Barbus cyclolepis & & Alosa fallax & Aspius aspius \\
\hline & Cottus gobio & Barbus peloponnesius & & Aspius aspius & Barbatula barbatula \\
\hline & Cottus poecilopus & Chondrostoma nasus & & Barbus barbus & Barbus barbus \\
\hline & Eudontomyzon mariae & Coregonus lavaretus & & Barbus cyclolepis & Barbus cyclolepis \\
\hline & Gobio gobio & Cottus gobio & & Barbus peloponnesius & Barbus peloponnesius \\
\hline & Gobio kesslerii & Cottus poecilopus & & Chondrostoma nasus & Chondrostoma nasus \\
\hline & Hucho hucho & Eudontomyzon mariae & & Cottus gobio & Coregonus albula \\
\hline & Lampetra planeri & Eupallasella perenurus & & Cottus poecilopus & Coregonus lavaretus \\
\hline & Lota lota & Gobio kesslerii & & Ctenopharyngodon idella & Coregonus peled \\
\hline & Oncorhynchus mykiss & Hucho hucho & $\frac{e_{0}^{x}}{d}$ & Eudontomyzon mariae & Eudontomyzon mariae \\
\hline & Pelecus cultratus & Lampetra fluviatilis & $\Xi$ & Gobio gobio & Hucho hucho \\
\hline & Phoxinus phoxinus & Lampetra planeri & $\Xi$ & Gobio kesslerii & Lampetra fluviatilis \\
\hline & Proterorhinus marmoratus & Misgurnus fossilis & $\stackrel{\overrightarrow{3}}{3}$ & Hucho hucho & Lampetra planeri \\
\hline & Romanogobio vladykovi & Phoxinus phoxinus & & Hypophthalmichthys molitrix & Leuciscus cephalus \\
\hline & Salmo salar & Proterorhinus marmoratus & & Lampetra fluviatilis & Leuciscus leuciscus \\
\hline & Salmo trutta fario & Rhodeus amarus & & Lampetra planeri & Lota lota \\
\hline & Salmo trutta lacustris & Salmo salar & & Leuciscus cephalus & Neogobius melanostomus \\
\hline & Salmo trutta trutta & Salmo trutta fario & & Leuciscus leuciscus & Oncorhynchus mykiss \\
\hline & Salvelinus fontinalis & Salmo trutta lacustris & & Oncorhynchus mykiss & Osmerus eperlanus \\
\hline & Thymallus thymallus & Salmo trutta trutta & & Petromyzon marinus & Petromyzon marinus \\
\hline & & Salvelinus fontinalis & & Romanogobio vladykovi & Phoxinus phoxinus \\
\hline & & Thymallus thymallus & & Salmo salar & Salmo salar \\
\hline & & $\underline{\text { Tinca tinca }}$ & & Salmo trutta fario & Salmo trutta fario \\
\hline & & Umbra krameri & & Salmo trutta lacustris & Salmo trutta lacustris \\
\hline & & Vimba vimba & & Salmo trutta trutta & Salmo trutta trutta \\
\hline & & & & Salvelinus fontinalis & Salvelinus fontinalis \\
\hline & & & & Salvelinus alpinus & Thymallus thymallus \\
\hline & & & & Thymallus thymallus & Vimba vimba \\
\hline & & & & Vimba vimba & \\
\hline
\end{tabular}

$\mathrm{EFI}+\mathrm{PL}=$ new European Fish Index adapted to Polish rivers; Ni.O2.Intol = density of species intolerant to oxygen depletion, (requiring more than $6 \mathrm{mg} \cdot \mathrm{dm}^{-3} \mathrm{O}_{2}$ ), Ni.Hab.Intol.150 = density of species intolerant to habitat degradation — specimens $\leq 150 \mathrm{~mm}$ (total length), Ric.RH.Par $=$ richness (number of rheopar species) requiring a rheophilic reproduction habitat, Ni.LITHO $=$ density of species requiring lithophilic reproduction habitat; Introduced and invasive species are marked with bold font and species not characteristic for Salmonid Index metrics are underlined (After: Anonymous 2009, Bady et al. 2009); Species names are given according to the list in Anonymous (2009).

velocity, lower oxygen concentrations, and higher natural Fisheries Institute. The EFI+ method, adapted to Polish acidification level. In such rivers litophilic and reophilic conditions as EFI+PL, was applied to the majority of fish species are naturally less abundant (Szlakowski et al. mountain, upland, and lowland river types, excluding:

2004). The EFI+ index should be also applied with caution • Organic rivers;

to large rivers (with catchment area exceeding 10000 - Rivers connecting lakes;

$\mathrm{km}^{2}$ ), and to all rivers sampled by boat. Other limitations $\bullet$ Large lowland rivers.

are related to low species number and low fish density_ $\quad$ For those river types, specific sets of IBI_PL (typesites with only one species or with fewer than 30 fish specific modification of Index of Biotic Integrity for caught should be treated with caution (Anonymous 2009). Polish rivers) metrics were proposed. Also a specific index

Poland started to implement fish-based monitoring of for diadromous fish species (D), based on the original rivers in 2011-2013 in a project financed by the Ministry EFI+ diadromous index, was applied to the majority of of Environment, conducted by several institutions and river types, excluding organic rivers and rivers connecting universities, led by the Stanisław Sakowicz Inland lakes. A software combining all three indices and creating 
an MS Access database for river ecological status/potential assessment based on fish as a biological quality element was also developed. The EFI+PL and IBI PL indices were accepted as a Polish national method in standard environment monitoring system (Anonymous 2016). The present paper presents results of the first application of those new methods to assess ecological status or ecological potential at almost 500 sites on Polish rivers.

\section{MATERIALS AND METHODS}

Fish data were collected using electrofishing technique according to the CEN standard (Anonymous 2003). Single electrofishing with one anode on small rivers and two anodes on large ones was conducted. For rivers less than $70-\mathrm{cm}$ deep, wading electrofishing was used. For rivers with shallow and deep parts-mixed wading and boat electrofishing technique was applied, while rivers deeper than $70 \mathrm{~cm}$ were fished from a boat. In small and mediumsize streams $(<10 \mathrm{~m}$ width), the whole riverbed width was fished, while in large rivers partial electrofishing or sampling along one shore was conducted. General rule of sampling at least 20 times the river bed width was followed, except for very small streams, where a minimum distance of $100 \mathrm{~m}$ was sampled and for very large rivers, where a distance of at least $1000 \mathrm{~m}$ was adopted as sufficient sampling site length. All fish caught were identified to species. Fish number by total length class was recorded. According to the EFI+ method two length classes were distinguished: $\leq 150 \mathrm{~mm}$ and $>150 \mathrm{~mm}$ (Anonymous 2009). A cumulative weight per species was also measured. All fish, except some invasive alien species, were released to the same site immediately after measurements. Invasive species were killed in a humanitarian way, according to Polish law (Anonymous 2011a). In total, 493 sites located in 431 surface water bodies were sampled in 2011-2012, during two sampling campaigns between 15 of August and end of October (Fig. 1).

Environmental data describing each sampling site were collected both in the field and using literature or Internet facilities. The coordinates of each site were recorded with GPS, and the parameters such as the site length $(\mathrm{m})$, river width $(\mathrm{m})$, and depth $(\mathrm{m})$ were measured. Additional measurements, such as water temperature, conductivity, and flow velocity (Table 2) were collected for a subset of sites. River morphological characteristics and data on bottom substrate type, bank regulation, riparian vegetation, and neighbouring land use (up to $50 \mathrm{~m}$ from the riverbed) were also collected for each site at a river segment scale. River segment was determined as in the EFI+ method, i.e., $1 \mathrm{~km}$ for small rivers $\left(<100 \mathrm{~km}^{2}\right.$ catchment), $5 \mathrm{~km}$ for medium size rivers $\left(100-1000 \mathrm{~km}^{2}\right.$ catchment) and $10 \mathrm{~km}$ for large rivers $\left(>1000 \mathrm{~km}^{2}\right.$ catchment). These data were collected during field observations and recorded in descriptive classes. Parameters such as the site altitude, river slope, catchment area, river order, and the mean air temperature were obtained from digital maps* available on the Internet, other on-line databases, or literature (Czarnecka 2005). Data on Polish river types (physical-factor classification) (Anonymous 2011b) and modification status (e.g., natural, highly modified, or artificial water body) were provided by the Chief Inspectorate for Environment Protection, Warsaw, Poland.

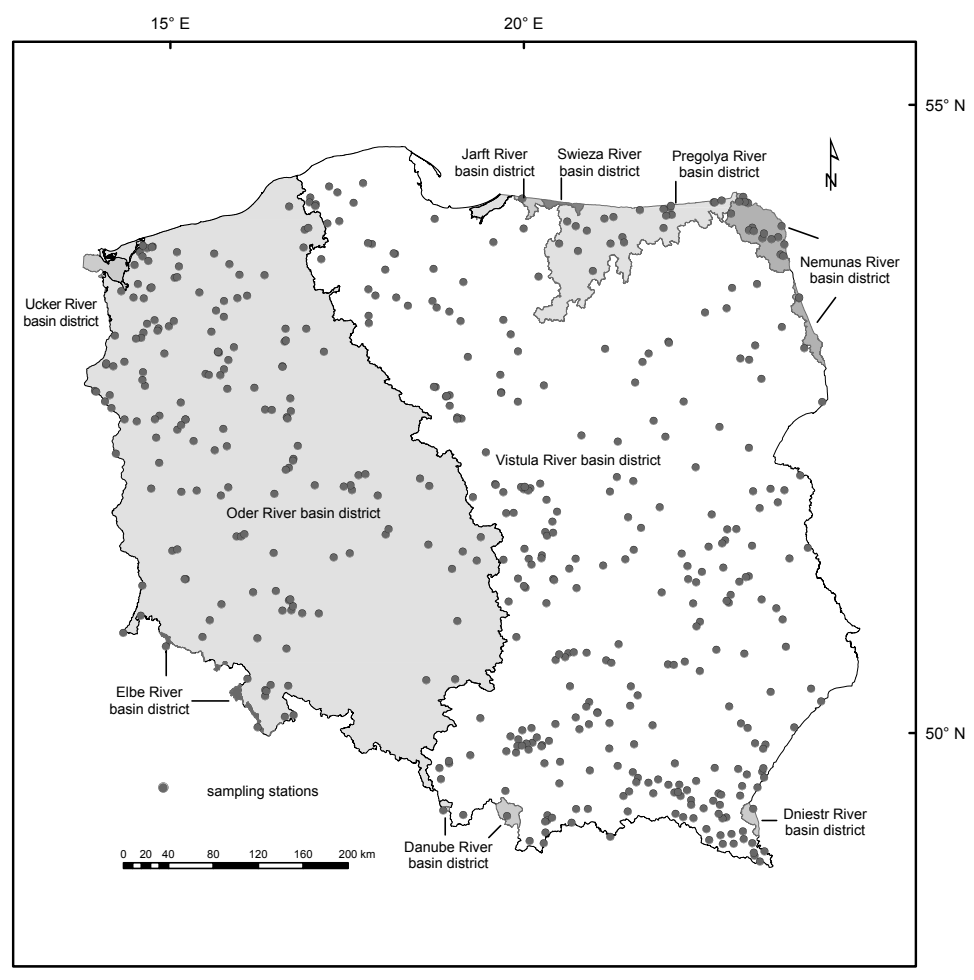

Fig. 1. Distribution of 493 sites sampled within the monitoring programme in 2011-2012 in main river catchments in Poland 
Table 2

Variables needed to calculate EFI+PL and IBI_PL indices (Obligatory variables are bolded)

\begin{tabular}{|c|c|c|c|}
\hline Sampling event & Sampling method & Environmental variable & Fish variable \\
\hline Ordinal number & Sampling location & Altitude & Species name \\
\hline Number & Method & Natural lake upstream & Total number run 1 \\
\hline Site code & Fished area & Geomorphology & Number below $150 \mathrm{~mm}$ \\
\hline Longitude & Research team & Former flood plain & Number over 150 mm \\
\hline Latitude & $\begin{array}{l}\text { Type of electric power } \\
\text { generator }\end{array}$ & Water source & Weight of fish caught \\
\hline Site name & Power of generator & Upstream drainage area & $\begin{array}{l}\text { Number of diseased fish } \\
\text { or hybrids }\end{array}$ \\
\hline River name & Ampere & Distance from source & \\
\hline Stream order classification & Voltage & River slope & \\
\hline Code for water body & Length of fished area & Air temperature mean annual & \\
\hline Code of monitoring point & Part of riverbed sampled & $\begin{array}{l}\text { Air temperature mean } \\
\text { January }\end{array}$ & \\
\hline Voivodeship & Mean depth & Air temperature mean July & \\
\hline HMWB & Width of fished area & Former sediment size & \\
\hline $\begin{array}{l}\text { Physically-classified river } \\
\text { type }\end{array}$ & Water temperature & & \\
\hline Geological river type & Velocity & & \\
\hline Main stem/river recipient & Conductivity & & \\
\hline Basin/river region & Land use & & \\
\hline Ecoregion & $\begin{array}{l}\text { River bank revetment/ } \\
\text { strengthening }\end{array}$ & & \\
\hline Day & Trees & & \\
\hline Month & Shrubs & & \\
\hline \multirow[t]{4}{*}{ Year } & Bottom diversity & & \\
\hline & Flow disturbance & & \\
\hline & Reservoir upstream & & \\
\hline & Wetted width & & \\
\hline
\end{tabular}

$\mathrm{EFI}+\mathrm{PL}=$ new European Fish Index adapted to Polish rivers; IBI_PL = type-specific modification of Index of Biotic Integrity for Polish rivers.

All data collected (Table 2) were gathered in an MS Excel file, which is an input to the EFI+IBI PL software. The next step was to populate the additional MS Excel input file for diadromous fishes, which was based on the original EFI+ Diadromous Index (Anonymous 2009). Data on historical occurrence of diadromous fish species were taken from the literature (review in Brylińska 2000, Wiśniewolski and Engel 2006, Błachuta et al. 2010), while the information on present occurrence of those species was gathered from available catch data, observations by fishery administrators of waters, including the Polish Angling Association, and from recent literature (review in Wiśniewolski and Engel 2006, Błachuta et al. 2010).

Finally the software calculated EFI+PL and IBI PL index values and assessed the class of ecological status (for natural water bodies) or ecological potential (for highly modified or artificial bodies of water) (Anonymous 2000). This was done according to class range for EFI+ and IBI methods, ascribed to particular river types (physical-factor classification), according to the Ordinance of the Minister of Environment (Anonymous 2011b), as shown in Table 3. The software transcribed all data from input files and assessment results into the MS Access database. Following the EFI+ Manual
(Anonymous 2009), the expert verification of automatic site classification to salmonid and cyprinid river type was conducted. The software indicated cases where high risk of river type misclassification occurred, due to lack of accordance between physical parameters (river slope and bottom substrate type) and percentage of sensitive salmonid species. For those sites an expert verification was necessary. Subsequently a mean index score for water bodies (for which more than one site was sampled) was calculated as an arithmetic mean of EFI+PL or IBI PL scores. Next the final ecological status/potential class was assessed for those water bodies, according to class range (Table 3, Anonymous 2016). For all water bodies, excluding organic rivers and rivers connecting lakes, the expert had also to include the value of $\mathrm{D}$ indexlowering final ecological status/potential class, assessed by EFI+PL or IBI_PL index, by one in case of D index value $<0.5$ (Table 3 , Anonymous 2016).

Fish species used in the Polish method (EFI+IBI PL) are listed in Table 4.

The presently reported study has been carried out in accordance with Polish regulations, i.e., all permissions for fish sampling: from local administration (Voivodship offices), Regional Directorates for Environment Protection and fishery managers were obtained. 
Table 3

Range of values of EFI+PL and IBI_PL used for assessment of ecological status/potential class based on fish data (Anonymous 2016)

\begin{tabular}{|c|c|c|c|c|c|c|c|c|}
\hline \multirow{2}{*}{\multicolumn{2}{|c|}{$\begin{array}{c}\text { Name of index defining } \\
\text { ecological status/potential of } \\
\text { rivers } \\
\text { High/Max. }\end{array}$}} & \multicolumn{5}{|c|}{$\begin{array}{c}\text { Range of values of index defining ecological status/potential } \\
\text { of rivers }\end{array}$} & \multicolumn{2}{|c|}{ Diadromous Index } \\
\hline & & High/Max. & Good & Moderate & Poor & $\mathrm{Bad}$ & $0.50-1.00$ & $<0.50$ \\
\hline $\begin{array}{l}\text { EFI+PL for } \\
\text { salmonid rivers }\end{array}$ & & $0.911-1.000$ & $0.755-0.911$ & $0.503-0.755$ & $0.252-0.503$ & $0.000-0.252$ & $\begin{array}{l}\text { Remains } \\
\text { unchanged }\end{array}$ & $\begin{array}{l}\text { One class } \\
\text { lower }\end{array}$ \\
\hline \multirow[t]{2}{*}{$\begin{array}{l}\text { EFI+PL for } \\
\text { cyprinid rivers }\end{array}$} & Wading & $0.939-1.000$ & $0.655-0.939$ & $0.437-0.655$ & $0.218-0.437$ & $0.000-0.218$ & $\begin{array}{l}\text { Remains } \\
\text { unchanged }\end{array}$ & $\begin{array}{l}\text { One class } \\
\text { lower }\end{array}$ \\
\hline & Boating & $0.917-1.000$ & $0.562-0.917$ & $0.375-0.562$ & $0.187-0.375$ & $0.000-0.187$ & $\begin{array}{c}\text { Remains } \\
\text { unchanged }\end{array}$ & $\begin{array}{c}\text { One class } \\
\text { lower }\end{array}$ \\
\hline \multirow[t]{3}{*}{ IBI_PL } & $\begin{array}{l}\text { Large lowland } \\
\text { river }\end{array}$ & $0.883-1.000$ & $0.750-0.882$ & $0.600-0.749$ & $0.400-0.599$ & $0.000-0.399$ & $\begin{array}{l}\text { Remains } \\
\text { unchanged }\end{array}$ & $\begin{array}{l}\text { One class } \\
\text { lower }\end{array}$ \\
\hline & Organic rivers & $0.883-1.000$ & $0.750-0.882$ & $0.600-0.749$ & $0.400-0.599$ & $0.000-0.399$ & Not used & \\
\hline & $\begin{array}{c}\text { Rivers } \\
\text { connecting } \\
\text { lakes }\end{array}$ & $0.883-1.000$ & $0.750-0.882$ & $0.600-0.749$ & $0.400-0.599$ & $0.000-0.399$ & Not used & \\
\hline
\end{tabular}

EFI + PL $=$ new European Fish Index adapted to Polish rivers; IBI_PL = type-specific modification of Index of Biotic Integrity for Polish rivers; $\mathrm{EFI}+\mathrm{PL}$ index = class range according to EFI+ Manual (Anonymous 2009) for all Polish river types (physical-factor classification), except large lowland rivers, organic rivers and rivers connecting lakes; IBI PL index $=$ class range established for specific physicallyclassified types of rivers; Diadromous index (D) complement EFI+PL and IBI_PL of a parameter connected with occurrence of diadromous fish; Class ranges are the same for assessment of ecological status and ecological potential of rivers; "Large lowland river" = physicallyclassified type of flowing waters (Anonymous 2011b); Diadromous index (D) is modified "Ids.ric.diadromous" (index diadromous species richness) from EFI+ method (Anonymous 2009).

Table 4

Basic ecological guilds of fish occurring in Poland considered by EFI+IBI_PL program metrics

\begin{tabular}{|c|c|c|c|c|c|}
\hline \multirow[b]{2}{*}{ Species (program unit) } & \multicolumn{5}{|c|}{ Ecological guild } \\
\hline & Trophic & Spawning & Flow velocity & Habitat & $\begin{array}{c}\text { Species } \\
\text { origin }\end{array}$ \\
\hline Eudontomyzon mariae & $F_{f}$ & $\mathrm{~L}$ & $\mathrm{R}$ & $\mathrm{B}$ & $\mathrm{N}$ \\
\hline Lampetra fluviatilis & $F_{f}$ & $\mathrm{~L}$ & $\mathrm{R}$ & $\mathrm{B}$ & $\mathrm{N}$ \\
\hline Lampetra planeri & $F_{f}$ & $\mathrm{~L}$ & $\mathrm{R}$ & $\mathrm{B}$ & $\mathrm{N}$ \\
\hline Petromyzon marinus & $F_{f}$ & $\mathrm{~L}$ & $\mathrm{R}$ & $\mathrm{B}$ & $\mathrm{N}$ \\
\hline Acipenser oxyrinchus & I & $\mathrm{L}$ & $\mathrm{R}$ & $\mathrm{B}$ & $\mathrm{N}$ \\
\hline Acipenser sturio & I & $\mathrm{L}$ & $\mathrm{R}$ & $\mathrm{B}$ & $\mathrm{N}$ \\
\hline Anguilla anguilla & $\mathrm{P} / \mathrm{I}$ & Spec & $\mathrm{L}_{\mathrm{m}}$ & $\mathrm{B}$ & $\mathrm{N}$ \\
\hline Coregonus lavaretus & $F_{f}$ & PS & $\mathrm{Lm}$ & WC & $\mathrm{N}$ \\
\hline Coregonus peled & $F_{f}$ & PS & $\mathrm{Lm}$ & WC & AI \\
\hline Coregonus albula & $F_{f}$ & F-PS & $\mathrm{Lm}$ & WC & $\mathrm{N}$ \\
\hline Hucho hucho & $\mathrm{P}$ & $\mathrm{L}$ & $\mathrm{R}$ & WC & $\mathrm{AI}^{*}$ \\
\hline Oncorhynchus mykiss & $\mathrm{I} / \mathrm{P}$ & $\mathrm{L}$ & $\mathrm{R}$ & WC & $\mathrm{AI}$ \\
\hline Salmo salar & $\mathrm{P}$ & $\mathrm{L}$ & $\mathrm{R}$ & WC & $\mathrm{N}$ \\
\hline "Salmo trutta fario" & $\mathrm{I} / \mathrm{P}$ & $\mathrm{L}$ & $\mathrm{R}$ & WC & $\mathrm{N}$ \\
\hline "Salmo trutta lacustris" & $\mathrm{P}$ & $\mathrm{L}$ & $\mathrm{R}$ & WC & $\mathrm{N}$ \\
\hline "Salmo trutta trutta" & $\mathrm{P}$ & $\mathrm{L}$ & $\mathrm{R}$ & WC & $\mathrm{N}$ \\
\hline Salvelinus alpinus & $\mathrm{I} / \mathrm{P}$ & $\mathrm{L}$ & $\mathrm{R}$ & WC & AI \\
\hline Salvelinus fontinalis & $\mathrm{I} / \mathrm{P}$ & $\mathrm{L}$ & $\mathrm{R}$ & WC & AI \\
\hline Thymallus thymallus & I & $\mathrm{L}$ & $\mathrm{R}$ & WC & $\mathrm{N}$ \\
\hline Osmerus eperlanus & $F_{f}$ & L-pe & $\mathrm{Lm}$ & WC & $\mathrm{N}$ \\
\hline Esox lucius & $\mathrm{P}$ & $\mathrm{F}$ & $\mathrm{Lm}$ & WC & $\mathrm{N}$ \\
\hline Umbra krameri & $\mathrm{O}$ & $\mathrm{F}$ & $\mathrm{Lm}$ & $\mathrm{B}$ & AI \\
\hline "Abramis ballerus" & $F_{f}$ & $\mathrm{~F}$ & $\mathrm{Lm}$ & WC & $\mathrm{N}$ \\
\hline "Abramis bjoerkna" & I & F-1 & $\mathrm{Lm}$ & WC & $\mathrm{N}$ \\
\hline Abramis brama & $\mathrm{O}$ & $\mathrm{F}$ & $\mathrm{Lm}$ & $\mathrm{B}$ & $\mathrm{N}$ \\
\hline Abramis sapa & $\mathrm{I}$ & $\mathrm{F}-1$ & $\mathrm{R}$ & $\mathrm{B}$ & $\mathrm{N}$ \\
\hline
\end{tabular}

Table continues on next page. 
Table 4 cont.

\begin{tabular}{|c|c|c|c|c|c|}
\hline \multirow[b]{2}{*}{ Species (program unit) } & \multicolumn{5}{|c|}{ Ecological guild } \\
\hline & Trophic & Spawning & Flow velocity & Habitat & $\begin{array}{c}\text { Species } \\
\text { origin }\end{array}$ \\
\hline Alburnoides bipunctatus & I & $\mathrm{L}$ & $\mathrm{R}$ & $\mathrm{WC}$ & $\mathrm{N}$ \\
\hline Alburnus alburnus & $\mathrm{I}$ & F-1 & $\mathrm{R} / \mathrm{Lm}$ & WC & $\mathrm{N}$ \\
\hline Alosa alosa & $\mathrm{F}_{\mathrm{f}}$ & $\mathrm{Pe}$ & $\mathrm{Lm} / \mathrm{R}$ & WC & $\mathrm{N}$ \\
\hline Alosa fallax & $\mathrm{F}_{\mathrm{f}}$ & $\mathrm{Pe}$ & $\mathrm{Lm} / \mathrm{R}$ & $\mathrm{WC}$ & $\mathrm{N}$ \\
\hline Aspius aspius & $\mathrm{P}$ & $\mathrm{L}$ & $\mathrm{R}$ & WC & $\mathrm{N}$ \\
\hline Barbus barbus & I & $\mathrm{L}$ & $\mathrm{R}$ & $\mathrm{B}$ & $\mathrm{N}$ \\
\hline Barbus peloponnesius & I & $\mathrm{L}$ & $\mathrm{R}$ & $\mathrm{B}$ & $\mathrm{N}$ \\
\hline "Barbus cyclolepis" & I & $\mathrm{L}$ & $\mathrm{R}$ & $\mathrm{B}$ & $\mathrm{N}$ \\
\hline Carassius carassius & $\mathrm{O}$ & $\mathrm{F}$ & $\mathrm{Lm}$ & $\mathrm{B}$ & $\mathrm{N}$ \\
\hline Carassius gibelio & $\mathrm{O}$ & $\mathrm{F}$ & $\mathrm{Lm}$ & $\mathrm{B}$ & $\mathrm{A} / \mathrm{AI}$ \\
\hline Chondrostoma nasus & $\mathrm{H}$ & $\mathrm{L}$ & $\mathrm{R}$ & B & $\mathrm{N}$ \\
\hline Ctenopharyngodon idella & $\mathrm{H}$ & $\mathrm{Pe}$ & $\mathrm{R} / \mathrm{Lm}$ & WC & AI \\
\hline Cyprinus carpio & $\mathrm{O}$ & $\mathrm{F}$ & $\mathrm{Lm}$ & $\mathrm{B}$ & AI \\
\hline "Eupallasella perenurus" & $\mathrm{O}$ & $\mathrm{F}$ & $\mathrm{Lm}$ & $\mathrm{B}$ & $\mathrm{N}$ \\
\hline Gobio gobio & $\mathrm{I}$ & PS & $\mathrm{R}$ & $\mathrm{B}$ & $\mathrm{N}$ \\
\hline "Gobio kessleri" & I & PS & $\mathrm{R}$ & $\mathrm{B}$ & $\mathrm{N}$ \\
\hline Hypophthalmichthys molitrix & $F_{f}$ & $\mathrm{Pe}$ & $\mathrm{R} / \mathrm{Lm}$ & WC & AI \\
\hline Leucaspius delineatus & $\mathrm{O}^{1}$ & $\mathrm{~F}$ & $\mathrm{Lm}$ & WC & $\mathrm{N}$ \\
\hline "Leuciscus cephalus" & $\mathrm{P} / \mathrm{I}$ & $\mathrm{L}$ & $\mathrm{R}$ & WC & $\mathrm{N}$ \\
\hline Leuciscus idus & $\mathrm{O}$ & $\mathrm{F}$ & $\mathrm{R} / \mathrm{Lm}$ & WC & $\mathrm{N}$ \\
\hline Leuciscus leuciscus & I & F-1 & $\mathrm{R}$ & WC & $\mathrm{N}$ \\
\hline Pelecus cultratus & $\mathrm{I} / \mathrm{P}$ & $\mathrm{Pe}$ & $\mathrm{R}$ & WC & $\mathrm{N}$ \\
\hline Phoxinus phoxinus & $\mathrm{O}$ & $\mathrm{L}$ & $\mathrm{R}$ & WC & $\mathrm{N}$ \\
\hline Pseudorasbora parva & I & F-1 & $\mathrm{R}$ & $\mathrm{B}$ & A \\
\hline Rhodeus amarus & $\mathrm{H}$ & OS & $\mathrm{Lm} / \mathrm{R}$ & WC & $\mathrm{N}$ \\
\hline Romanogobio vladykovi & I & PS & $\mathrm{R}$ & $\mathrm{B}$ & $\mathrm{N}$ \\
\hline Rutilus rutilus & $\mathrm{O}$ & $\mathrm{F}$ & $\mathrm{Lm}$ & WC & $\mathrm{N}$ \\
\hline Scardinius erythrophthalmus & $\mathrm{H}$ & $\mathrm{F}$ & $\mathrm{Lm}$ & WC & $\mathrm{N}$ \\
\hline Tinca tinca & $\mathrm{I}$ & $\mathrm{F}$ & $\mathrm{Lm}$ & $\mathrm{B}$ & $\mathrm{N}$ \\
\hline Vimba vimba & I & $\mathrm{L}$ & $\mathrm{R}$ & $\mathrm{B}$ & $\mathrm{N}$ \\
\hline "Barbatula barbatula" & I & PS & $\mathrm{R}$ & $\mathrm{B}$ & $\mathrm{N}$ \\
\hline Cobitis taenia & I & $\mathrm{F}$ & $\mathrm{R}$ & $\mathrm{B}$ & $\mathrm{N}$ \\
\hline Misgurnus fossilis & I & $\mathrm{F}$ & $\mathrm{Lm}$ & $\mathrm{B}$ & $\mathrm{N}$ \\
\hline Sabanejewia aurata & I & F-1 & $\mathrm{R}$ & $\mathrm{B}$ & $\mathrm{N}$ \\
\hline Ameiurus nebulosus & I & $\mathrm{F}$ & $\mathrm{Lm}$ & $\mathrm{B}$ & A \\
\hline Silurus glanis & $\mathrm{P}$ & $\mathrm{F}$ & $\mathrm{R}$ & $\mathrm{B}$ & $\mathrm{N}$ \\
\hline Lota lota & $\mathrm{P} / \mathrm{I}$ & L-pe & $\mathrm{R} / \mathrm{Lm}$ & $\mathrm{B}$ & $\mathrm{N}$ \\
\hline Gasterosteus aculeatus & I & $\mathrm{F}$ & $\mathrm{Lm}$ & WC & $\mathrm{N}$ \\
\hline Pungitius pungitius & I & $\mathrm{F}$ & $\mathrm{Lm}$ & WC & $\mathrm{N}$ \\
\hline Cottus gobio & I & $\mathrm{L}$ & $\mathrm{R}$ & $\mathrm{B}$ & $\mathrm{N}$ \\
\hline Cottus poecilopus & I & $\mathrm{L}$ & $\mathrm{R}$ & $\mathrm{B}$ & $\mathrm{N}$ \\
\hline Neogobius fluviatilis & I & $\mathrm{L}$ & $\mathrm{Lm}$ & $\mathrm{B}$ & A \\
\hline Neogobius gymnotrachelus & I & $\mathrm{L}$ & $\mathrm{Lm}$ & $\mathrm{B}$ & A \\
\hline Neogobius melanostomus & $\mathrm{I} / \mathrm{P}$ & $\mathrm{L}$ & $\mathrm{Lm}$ & $\mathrm{B}$ & A \\
\hline "Proterorhinus marmoratus" & I & $\mathrm{L}$ & $\mathrm{Lm}$ & $\mathrm{B}$ & A \\
\hline Perccottus glenii & I & $\mathrm{F}$ & $\mathrm{Lm}$ & $\mathrm{B}$ & A \\
\hline Gymnocephalus cernuus & I & F-1 & $\mathrm{Lm}$ & WC & $\mathrm{N}$ \\
\hline Perca fluviatilis & $\mathrm{I} / \mathrm{P}$ & F-1 & $\mathrm{Lm} / \mathrm{R}$ & WC & $\mathrm{N}$ \\
\hline Sander lucioperca & $\mathrm{P}$ & $\mathrm{F}$ & $\mathrm{Lm} / \mathrm{R}$ & WC & $\mathrm{N}$ \\
\hline
\end{tabular}

The fish species names used by the program are in fact "program units". Those with disputable validity or spelling are presented within quotation marks; $\mathrm{F}_{\mathrm{f}}=$ filter feeders, $\mathrm{P}=$ piscivorous; $\mathrm{I}=$ invertivorous; $\mathrm{P} / \mathrm{I}=$ relatively piscivorous; $\mathrm{O}=$ omnivorous; $\mathrm{H}=$ herbivorous; $\mathrm{L}=$ lithophilous; F = fitophilous; F-1 = fito-lithophilous; PS = psammophilous; OS = ostracophilous; L-pe = litho-pelagophilous; Pe = pelagophilous; $\mathrm{R}=$ reolimnic; $\mathrm{Lm}=$ limnophilic; $\mathrm{WC}=$ water column; $\mathrm{B}=$ benthic; $\mathrm{N}=$ native species; $\mathrm{A}=$ alien species; $\mathrm{AI}=$ alien $\mathrm{species}$ from stocking. 


\section{RESULTS}

In relation to the original EFI+ method (Anonymous 2009), some modifications were done to adjust the index to specific conditions of Polish rivers and their fish assemblages. The most important changes were as follows:

- Assigning the eastern part of Vistula River catchment, as well as small parts of the Nemunas and Pregolya rivers catchments located in Poland (Fig. 1), to the Central Plains Ecoregion - in order to avoid the division of one large river catchment between two ecoregions (Central Plains and Eastern Plains). Such division was proposed by Illies (1978) and later adopted by the EFI+ method. We believe it is not appropriate due to strong similarities of fish assemblages in those rivers (Backiel et al. 2000).

- Assigning a small area of the Dniester River catchment located in Poland ( 2 small streams) to the Vistula River catchment, due to lack of the Dniester River in the $\mathrm{EFI}+$ software and due to similarities of fish assemblages in those rivers and neighbouring streams of the Vistula catchment (Kukuła and Bylak 2010).

Adapting the original EFI+ Diadromous index to Polish conditions by adding the Vimba vimba (Linnaeus, 1758) - migratory fish species important in the Polish ichthyofauna (Wiśniewolski and Engel 2006). This species was not included in the original index (Anonymous 2009) due to its limited occurrence in western and southern Europe.

The IBI_PL method was developed for these river types (physical-factor classification) that should not be assessed with EFI+ index (Anonymous 2009). The method was based on the original IBI index (Karr 1981, Karr et al. 1986) adjusted to Polish conditions. First, fish species important in Polish river ecosystems were classified into functional guilds i.e., trophic, spawning (Balon 1975), flow velocity, and habitat requirements (Table 4). Than IBI metrics were developed and point scores were ascribed for each metric using IBI methodology, including lines of maximal species richness (Karr 1981, Karr et al. 1986). First IBI application to Polish rivers was done by Szlakowski et al. 2004 and Buras et al. 2006 for the Biebrza and Nida river systems. For the IBI PL method groups of metrics were selected for particular river types (physical-factor classification). Lines of maximal species richness were determined based on a large dataset collected during the monitoring program. This dataset included rivers from each type (physical-factor classification) of various catchment size. Metrics were calibrated using a subset of relatively undisturbed sites for each river type (physical-factor classification). Finally, the IBI matrix for five river types was developed as follows:

- Large (catchment over $10000 \mathrm{~km}^{2}$ ) lowland rivers (sandy);

- Large lowland rivers (gravel);

- Organic rivers;

- Rivers connecting lakes (without salmonid species);

- Rivers connecting lakes (with salmonid species) (Table 5).

This matrix is included into EFI+IBI_PL software and used to calculate IBI_PL index for rivers of particular types, according to selected sets of metrics.
The method composed of two indices: modified EFI+ (EFI+PL) and newly developed IBI_PL was applied to the dataset collected during national monitoring programme in 2011 and 2012. Ecological status or potential, based on fish as biological quality element, was assessed for 488 out of 493 sites sampled (Table 6). For five sites $(1 \%)$, the assessment was not possible due to lack of fish in the samples. The EFI+PL index was calculated for 393 sites $(80 \%)$ and IBI PL for 95 sites $(19 \%)$. For $24 \%$ of sites assessed with EFI+PL very good and good ecological status or maximal and good ecological potential was found. The IBI PL index ranked $15 \%$ of sites as ecologically good, while only $4 \%$ as with a good ecological potential. None of sites was classified by this method into very good ecological state or maximal ecological potential. Both indices classified the highest percentage of sites into moderate ecological state/potential class, but for EFI+PL this was 35\% and for IBI_PL as much as 54\%-60\% of sites (Table 6).

\section{DISCUSSION}

The combination of two assessment methods: EFI+PL and IBI PL was adopted as a tool for river ecological status/potential assessment, based on fish as biological quality element, in standard environment monitoring system in Poland (Anonymous 2016). It also can serve as a foundation for development of sustainable inland fisheries management plans at the regional or global scale. Both indices respond to anthropogenic pressure at the site level - such as morphological and hydrological alterations, habitat degradation, or water pollution. First analysis indicates the consistence of classification for $77 \%$ of sites to high/good and below good ecological status by the EFI+PL/IBI_PL method and pressure index. A 73\% consistence of fish-based assessment and assessment based on other biological quality elements with additional physicochemical and hydromorphological parameters (Prus et al. 2016) were also found. The man-made factors effecting the entire catchment, especially obstacles in fish migration resulting in disruption of the river continuum (Vannote et al. 1980) are reflected by the third index (D), concerning the presence of diadromous fish species. It should be stressed that incorporation of this index in the Polish national method is a step towards restoration of fish migration channels. It is not a very common practice in the EU countries, as can be seen by comparing national methods presented in the Intercalibration Exercise (Anonymous unpublished*). However, a method for diadromous fish assessment, based on expert judgment, is used in Germany (Dußling et al. 2004, Anonymous unpublished*). The Polish method requires obligatory lowering of the ecological status/potential class calculated by one of main indices (EFI+PL or IBI_PL) — by one point - in case of lack of more than $50 \%$ of historically present diadromous fish species. It is a clear signal to all authorities responsible for water management that restoration of rivers connectivity is necessary to achieve good ecological status of water bodies (Wiśniewolski and 
Table 5

Metrics used for calculation of IBI_PL index, with information about impact on index value

\begin{tabular}{|c|c|c|c|c|c|c|}
\hline \multirow{2}{*}{ Metric (parameter) } & \multirow{2}{*}{$\begin{array}{l}\text { Effects } \\
\text { of the } \\
\text { metrics }\end{array}$} & \multicolumn{5}{|c|}{ Type of river } \\
\hline & & LLRS & LLRG & OR & RCLNS & RCLS \\
\hline \multicolumn{7}{|c|}{ 1. Richness of fish assemblages and proportion of species (number of species or percent of individuals) } \\
\hline Total number of fish species & $>$ & + & + & + & + & + \\
\hline Richness of lithophilous species & $>$ & & & + & + & \\
\hline Richness of water column species & $>$ & + & + & + & + & + \\
\hline Richness of benthic species & $>$ & + & + & + & + & + \\
\hline Richness of fish species typical for large rivers (LRF) & $>$ & + & & & & \\
\hline Species evenness index E & $>$ & & + & & & \\
\hline Percent of lithophilous species & $>$ & & + & & & + \\
\hline Percent of indicator species (IS) & $>$ & + & & & & \\
\hline Percent of Esox lucius & $>$ & & & + & + & + \\
\hline Percent of Rutilus rutilus & $<$ & + & & + & + & \\
\hline Percent of eutrophic species (ES) & $<$ & & + & & & \\
\hline Percent of salmonid species & $>$ & & & & & + \\
\hline \multicolumn{7}{|l|}{ 2. Proportion of trophic guilds (percent of individuals) } \\
\hline Percent of piscivores & $>$ & + & + & + & + & + \\
\hline Percent of relative piscivores & $>$ & & + & & & \\
\hline Percent of invertivores & $>$ & + & + & & & \\
\hline Percent of relative piscivores and invertivores & $>$ & & & + & + & + \\
\hline Percent of omnivores & $<$ & & & & & + \\
\hline Percent of omnivores except Rutilus rutilus & $<$ & + & + & + & + & \\
\hline \multicolumn{7}{|l|}{ 3. Abundance and health status of fish assemblages } \\
\hline Percent of diseased fish or fish hybrids & $<$ & + & + & + & + & + \\
\hline Abundance of fish expressed as a CPUE (catch per unit effort) & $>$ & + & + & + & + & + \\
\hline Percent of individuals of alien species & $<$ & + & + & + & + & + \\
\hline
\end{tabular}

IBI_PL = type-specific modification of Index of Biotic Integrity for Polish rivers; LLRS = large lowland river (sandy), LLRG = large lowland river (gravel), OR = organic river, RCLNS = river connecting lakes (without salmonid species), RCLS = river connecting lakes (with salmonid species); > increase of the metric value equivalents increase of index value; < increase of the metric value equivalents decrease of index value; LRF = Sander lucioperca, Aspius aspius, Barbus barbus, Abramis brama, Silurus glanis; IS = Esox lucius, Salmo trutta trutta, Rhodeus amarus, Scardinius erythrophthalmus, Vimba vimba, Chondrostoma nasus, Cottus gobio, Lampetra fluviatilis, Eudontomyzon mariae; IS = Rutilus rutilus, Alburnus alburnus, Leuciscus idus; CPUE = catch per unit effort.

Table 6

Assessment of ecological status/potential based on fish data collected on 488 monitoring sites within 2011-2012

\begin{tabular}{|c|c|c|c|c|c|c|c|c|c|c|c|}
\hline \multicolumn{6}{|c|}{ EFI+PL (393 sites monitored) } & \multicolumn{6}{|c|}{ IBI_PL (95 sites monitored) } \\
\hline \multicolumn{3}{|c|}{ Ecological status } & \multicolumn{3}{|c|}{ Ecological potential } & \multicolumn{3}{|c|}{ Ecological status } & \multicolumn{3}{|c|}{ Ecological potential } \\
\hline Class & $\begin{array}{l}\text { Number } \\
\text { of sites }\end{array}$ & $\%$ & Class & $\begin{array}{l}\text { Number } \\
\text { of sites }\end{array}$ & $\%$ & Class & $\begin{array}{c}\text { Number } \\
\text { of sites }\end{array}$ & $\%$ & Class & $\begin{array}{c}\text { Number } \\
\text { of sites }\end{array}$ & $\%$ \\
\hline 1 & 4 & 2 & 1 & 5 & 3 & 1 & 0 & 0 & 1 & 0 & 0 \\
\hline 2 & 49 & 22 & 2 & 36 & 21 & 2 & 7 & 15 & 2 & 2 & 4 \\
\hline 3 & 78 & 35 & 3 & 59 & 35 & 3 & 26 & 54 & 3 & 28 & 60 \\
\hline 4 & 60 & 27 & 4 & 46 & 27 & 4 & 12 & 25 & 4 & 17 & 36 \\
\hline 5 & 32 & 14 & 5 & 24 & 14 & 5 & 3 & 6 & 5 & 0 & 0 \\
\hline Sum & 223 & 100 & Sum & 170 & 100 & Sum & 48 & 100 & Sum & 47 & 100 \\
\hline
\end{tabular}

$\mathrm{EFI}+\mathrm{PL}=$ a new European Fish Index adapted to Polish rivers; IBI PL $=$ type-specific modification of Index of Biotic Integrity for Polish rivers; Class scores: $1=$ high $/$ maximal, $2=$ good, $3=$ moderate, $4=$ poor, $5=$ bad. 
Engel 2006). Thus, each new barrier that is built should result in the decreasing of the score. However, equipping of an existing barrier in a functioning fish pass (Anonymous 2002) may also lead to improvement of ecological status of upstream water bodies.

Initiated in 2013, the Polish national method (EFI+IBI_PL), presented in this paper, needs further testing and improvement. The amount of data gathered during first monitoring program (2011-2012) is too small for statistical analyses for each physically-classified river type (e.g., assessment of index response to human pressures). There is also not enough data to develop specific IBI indices for rivers of some physically-classified types that should not be assessed with EFI+ index. These types are: "Rivers located in a valley of large lowland river", and "Rivers under brackish [water] influence". Such specific IBI matrices will be developed and applied in the next version of EFI+IBI_PL software, during the new research-monitoring project, financed by the [Polish] Ministry of Environment that begun in 2014.

A few alien fish species occurring in Poland may positively influence the index score, as these species are listed in the EFI+ metrics. Obviously, the presence of alien species cannot be regarded as a positive indicator of biological quality (Adamczyk et al. 2013). In the IBI_ PL method there is a metric based on percentage of nonnative species in catch, decreasing the index value with increase of aliens share. There is also a group of species included in metrics for salmonid-dominated rivers, which are not characteristic for such environments - e.g., asp, Aspius aspius (Linnaeus, 1758) and tench, Tinca tinca (Linnaeus, 1758). Within the EFI+ project, those species were assigned to either of two guilds: intolerant to oxygen depletion or intolerant to habitat modifications (Anonymous 2009). Asp and tench, however, do not occur naturally in rivers dominated by salmonids (Table 1). To solve this problem it is necessary to block the effect of these two groups of species on a parameter value. This shall be introduced in the next version of modified EFI+PL software.

The presently reported results indicate lower biological quality/ecological potential when applying the IBI Pl index than when using EFI+PL (see Table 6). The rivers assessed with IBI_PL were not subjected to a higher anthropogenic pressure than those assessed with EFI+PL. So, the IBI class boundaries taken from original IBI method (Karr et al. 1986) should be calibrated with the human pressure data from Polish rivers, gathered in a similar way that in EFI+ project (Schinegger et al. 2011).

Finally, according to the EU procedures, the new Polish method needs to be intercalibrated with other national methods. It should be done also during the presently reported monitoring program. The intercalibration of EFI+PL method should be simple, as metrics of the EFI+ index were used as common metrics in the previous Intercalibration Exercise (Anonymous unpublished*), but more stress should be given to intercalibration of the IBI PL method, and to mentioned above class boundaries calibration for this index. Also special intercalibration exercise, planned in 2016-2017, will consider methods for assessment of ecological status or ecological potential in large rivers and Polish national method will be included in this process.

\section{ACKNOWLEDGEMENTS}

The study was supported by the three Polish organisations: the Stanisław Sakowicz Inland Fisheries Institute (IRS), Olsztyn (project No. S-005), the Chief Inspectorate of Environment Protection (GIOS), Poland, and the National Fund for Environmental Protection and Water Management (NFOSIGW) (agreement No. 441/2010/Wn-07/MN-BD/D).

\section{REFERENCES}

Adamczyk M., Prus P., Wiśniewolski W. 2013. Możliwości zastosowania Europejskiego Wskaźnika Ichtiologicznego (EFI+) do oceny stanu ekologicznego rzek Polski. [Possibilities of applying the European Fish Index (EFI+) to assess the ecological status of rivers in Poland.] Roczniki Naukowe Polskiego Związku Wędkarskiego 26: 21-51. [In Polish.] DOI: $10.12823 /$ sapaa.0860-648X.13002

Anonymous 2000. Directive of the European Parliament and the Council 2000/60/EC establishing a framework for community action in the field of water policy. Official Journal of the European Communities 43: 22.12.2000 L 327/1.

Anonymous 2002. FAO/DVWK Fish passesDesign, dimensions and monitoring. FAO, Rome and Deutscher Verband für Wasserwirtschaft und Kulturbau e.V. (DVWK).

Anonymous 2003. CEN EN 14011. Water Analysis: Fishing with electricity (EN 14011) for wadable and non-wadable rivers. European Committee for Standardization (CEN), Brussels, Belgium.

Anonymous 2004. Manual for the application of the European Fish Index-EFI. A fish-based method to assess the ecological status of European rivers in support of the Water Framework Directive. Version 1.1. January 2005. FAME Consortium.

Anonymous 2009. Manual for the application of the new European Fish Index-EFI+. A fish-based method to assess the ecological status of European running waters in support of the Water Framework Directive. June 2009. EFI+ Consortium. http://efi-plus.boku.ac.at/softwarel doc/EFI+Manual.pdf [With Annexes at: http://efi-plus. boku.ac.at/software/doc/Annexes.pdf]

Anonymous 2011a. Rozporządzenie Ministra Środowiska z dnia 9 września 2011 r. w sprawie listy roślin i zwierząt gatunków obcych, które w przypadku uwolnienia do środowiska przyrodniczego mogą zagrozić gatunkom rodzimym lub siedliskom przyrodniczym. [Ordinance of the Minister of Environment of 9 September 2011 on the list of alien plant and animal species, which in case of being released to the environment, may threaten native species or habitats.] Dziennik Ustaw 
Rzeczypospolitej Polskiej No. 210 (1260): 1232312325. [In Polish.]

Anonymous 2011b. Rozporządzenie Ministra Środowiska z dnia 9 listopada 2011 w sprawie klasyfikacji stanu ekologicznego, potencjału ekologicznego i stanu chemicznego jednolitych części wód powierzchniowych. [Ordinance of the Minister of Environment of 9 November 2011 on classification of ecological state, ecological potential, and chemical state of surface waters.] Dziennik Ustaw Rzeczypospolitej Polskiej No. 258 (1549): 15110-15132. [In Polish.]

Anonymous 2016. Rozporządzenie Ministra Środowiska z dnia 21 lipca 2016 r. w sprawie sposobu klasyfikacji stanu jednolitych części wód powierzchniowych oraz środowiskowych norm jakości dla substancji priorytetowych. [Ordinance of the Minister of Environment of 21 July 2016 on classification of the state of surface waters and environmental quality standards for priority substances.] Dziennik Ustaw Rzeczypospolitej Polskiej 2016 (1187): 1-95. [In Polish.]

Backiel T., Wiśniewolski W., Borzęcka I., Buras P., Szlakowski J., Woźniewski M. 2000. Fish assemblages in semi-natural and regulated large river stretches. Polish Archives of Hydrobiology 47 (1): 29-44.

Bady P., Pont D., Logez M., Veslot J. 2009. [Deliverable 4.1.] Report on the modelling of reference conditions and on the sensitivity of candidate metrics to anthropogenic pressures. EFI+ and Camagref. http://efi-plus.boku. ac.at/downloads/EFI+DeliverablesD4.1andD4.2.pdf

Balon E.K. 1975. Reproductive guilds of fishes: A proposal and definition. Journal of the Fisheries Research Board of Canada 32 (6): 821-864.

DOI: $10.1139 / \mathrm{f} 75-110$

Błachuta J., Rosa J., Wiśniewolski W., Zgrabczyński J., Bartel R., Białokoz W., Borzęcka I., Chybowski Ł., Depowski R., Dębowski P., Domagała J., Drożdżyński K., Hausa P., Kukuła K., Kubacka D., Kulesza K., Ligięza J., Ludwiczak M., Pawłowski M., Picińska-Faltynowicz J., Lisiński K., Witkowski A., Zgrabczyński D., Zgrabczyńska M. 2010. Ocena potrzeb i priorytetów udrożnienia ciągłości morfologicznej rzek w kontekście osiągnięcia dobrego stanu i potencjału części wód w Polsce. [Assessment of the needs and priorities for restoration of the morphological river patency in relation to achieving good ecological status and potential of some water bodies in Poland.] Krajowy Zarząd Gospodarki Wodnej, Warszawa. [In Polish.]

Brylińska M. (ed.) 2000. Ryby słodkowodne Polski. [Freshwater fishes of Poland.] Wydawnictwo Naukowe PWN, Warszawa, Poland. [In Polish.]

Buras P., Szlakowski J., Wiśniewolski W. 2006. Zespoły ryb jako element biocenozy w ocenie stopnia degradacji środowiska rzek. [Fish assemblages as biocenotic component used for assessment of the environmental degradation level of rivers.] Pp. 157171. In: Lemański J.F., Zabawa S. (eds.) Rekultywacja i rewitalizacja terenów zdegradowanych. Monografia. [Recultivation and revitalization of degraded areas. Monograph.] Futura. Polskie Zrzeszenie Inżynierów i Techników Sanitarnych Oddział Wielkopolski w Poznaniu, Poznań, Poland [In Polish.]

Buras P., Wiśniewolski W., Szlakowski J. 2004. Zespoły ryb w systemie Nidy jako kryterium waloryzacji środowiska rzecznego. [Fish assemblages of the Nida River system as a criterion of the riverine environment assessment.] Pp. 227-244. In: Heese T., Puchalski W. (eds.) Bliskie naturze kształtowanie dolin rzecznych. [Nature-friendly shaping of river valleys.] Wydawnictwo Politechniki Koszalińskiej, Koszalin, Poland: [In Polish.]

Czarnecka H. (ed.) 2005. Atlas podziału hydrograficznego Polski. Cz. 1. Mapy w skali 1: 200 000. Cz. 2. Zestawienie zlewni. [Atlas of the hydrographic division of Poland. Part 1. Maps in the scale 1 : 200 000. Part 2.-Catchment list.] IMGW, Warszawa. [In Polish.]

Dußling U., Berg R., Klinger H., Wolter C. 2014. Assessing the ecological status of river systems using fish assemblages. Handbuch Angewandte Limnologie: Grundlagen - Gewässerbelastung - Restaurierung - Aquatische Ökotoxikologie - Bewertung Gewässerschutz 4: 1-84.

DOI: $10.1002 / 9783527678488 . h b a l 2004006$

Fausch K.D., Lyons J., Karr J.R., Angermeier P.L. 1990. Fish communities as indicators of environmental degradation. American Fisheries Society Symposium 8: $123-144$.

Harrison T.D., Whitfield A.K. 2004. A multi-metric fish index to assess the environmental condition of estuaries. Journal of Fish Biology 65 (3): 683-710. DOI: $10.1111 / \mathrm{j} .0022-1112.2004 .00477 . \mathrm{x}$

Illies J. 1978. Limnofauna Europaea. 2. Aufl. G. FischerVerlag, Stuttgart, Germany.

Karr J.R. 1981. Assessment of biotic integrity using fish communities. Fisheries 6 (6): 21-27. DOI: 10.1577/1548-8446(1981)006<0021:AOBIUF >2.0.CO;2

Karr J.R., Fausch K.D., Angermeier P.L., Yant P.R., Schlosser I.J. 1986. Assessing biological integrity in running waters: a method and its rationale. Illinois National History Survey Special Publication 5, Urbana, Illinois, USA.

Kukuła K., Bylak A. 2010. Ichtiofauna górnego Strwiąża i Mszanki. [Fish fauna of the upper Strwiąż and Mszanka rivers.] Roczniki Bieszczadzkie 18: 178191. [In Polish.]

Pont D., Hugeney B., Beier U., Goffaux D., Melcher A., Noble R., Rogers C., Roset N., Schmutz S. 2006. Assessing river biotic condition at a continental scale: A European approach using functional meristics and fish assemblages. Journal of Applied Ecology 43 (1): 70-80.

DOI: $10.1111 / \mathrm{j} .1365-2664.2005 .01126 . \mathrm{x}$

Prus P., Wiśniewolski W., Adamczyk M. (eds.) 2016. Monitoring ichtiofauny $\mathrm{w}$ rzekach. Przewodnik metodyczny. [Ichthyofauna monitoring in rivers. A methodological guide.] Biblioteka Monitoringu 
Środowiska. Główny Inspektorat Ochrony Środowiska, Warszawa, Poland.

Prus P., Wiśniewolski W., Szlakowski J., Borzęcka I., Buras P., Błachuta J., Dębowski P., Jelonek M., Klich M., Kukuła K., Ligięza J., Przybylski M., Radtke G., Witkowski A., Żurek R. 2009. Rozwój ogólnoeuropejskiej metody oceny stanu ekologicznego rzek w oparciu o ichtiofaunę-Europejski Wskaźniki Ichtiologiczny (EFI+). [Development of a common European fish-based method for river ecological status assessment-European Fish Index (EFI+).] Nauka, Przyroda, Technologie 3: 3. [In Polish.]

Schinegger R., Trautwein C., Melcher A., Schmutz S. 2011. Multiple human pressures and their spatial patterns in European running waters. Water and Environment Journal 26 (2): 261-273.

DOI: $10.1111 / \mathrm{j} .1747-6593.2011 .00285 . \mathrm{x}$

Schmutz S., Cowx I.G., Haidvogl G., Pont D. 2007. Fish-based methods for assessing European running waters: A synthesis. Fisheries Management and Ecology 14 (6): 369-380.

DOI: $10.1111 / \mathrm{j} .1365-2400.2007 .00585 . \mathrm{x}$

Szlakowski J., Wiśniewolski W., Buras P. 2004. Wskaźnik Integralności Biotycznej(IBI)jako narzędzie do waloryzacji rzek w oparciu o zespoły ichtiofauny. [Index of Biotic Integrity (IBI) as a tool for fishbased validation of rivers.] Pp. 245-262. In: Heese T., Puchalski W. (eds.) Bliskie naturze kształtowanie dolin rzecznych. [Nature-friendly shaping of river valleys.] Wydawnictwo Politechniki Koszalińskiej, Koszalin, Poland. [In Polish.]

Vannote R.L., Minshall G.W., Cummins K.W., Sedell J.R., Cushing C.E. 1980. The river continuum concept. Canadian Journal of Fisheries and Aquatic Sciences 37 (1): 130-137. DOI: $\underline{10.1139 / \mathrm{f} 80-017}$

Wiśniewolski W., Błachuta J., Borzęcka I., Buras P., Dębowski P., Jelonek M., Klich M., Kukuła K., Prus P., Przybylski M., Radtke G., Szlakowski J., Witkowski A., Żurek R. 2006. Przetestowanie Europejskiego Indeksu Rybnego dla potrzeb oceny stanu ekologicznego rzek Polski. [Testing the European Fish Index as a tool for assessment of the river ecological status of Polish rivers.] Instytut Rybactwa Śródlądowego, Olsztyn, Poland. [In Polish.]

Wiśniewolski W., Engel J. (eds.) 2006. Restoring migratory fish and connectivity of rivers in Poland. Wydawnictwo Instytutu Rybactwa Śródlądowego, Olsztyn, Poland.

Received: 24 April 2016

Accepted: 7 April 2017

Published electronically: 30 June 2017 